\title{
Primates in Gabon - current status and distribution
}

\author{
A. Blom, M. P. T. Alers, A. T. C. Feistner, R. F. W. Barnes and K. L. Barnes
}

This paper examines the current status and distribution of primates in Gabon on the basis of data collected in the field between 1985 and 1988. There are at least 19 and possibly 21 species of primates definitely present in Gabon, making it one of the richest countries in the world for primates. Most of the species are still widespread and one, the sun-tailed guenon, is endemic. Hunting and habitat destruction are the main threats to the country's primates. The major problem at the moment is the opening up of previously inaccessible areas by logging companies and the Trans Gabon railway, which leads to an increase in hunting pressure. Several species are threatened; the mandrill/drill, the black colobus, and the sun-tailed guenon need special conservation measures. Suggestions for action are made and several new reserves have recently been proposed.

Until recently Gabon had been largely ignored by conservationists, but now international organizations, such as the International Union for Conservation of Nature and Natural Resources (IUCN) and the World Wide Fund for Nature, are recognizing its importance for biodiversity and rain-forest conservation (McShane, 1990). Gabon itself is also increasingly developing its own wildlife conservation and management policy. However, sufficient field data on the fauna are lacking, hampering attempts to assess conservation priorities.

Nationwide, only information on gorillas and chimpanzees is available, from a survey carried out between 1980 and 1983 (Tutin and Fernandez, 1984). In addition, a considerable amount of information on one small area, at the Institut de Recherche en Ecologie Tropicale (IRET) research station in Makokou, is available (e.g. Gautier and Gautier-Hion, 1969; Pages, 1972; Charles-Dominique, 1974; Gautier-Hion and Gautier, 1978), although much of this information is nearly 20 years old. A clear overview of status and distribution of most mammal species, including almost all the primates, is lacking. Because the larger species are usually the first to disappear when an ecosystem is disturbed by habitat destruction and/or hunting, a study of the distribution and density of large-bodied forest species can be used to indicate the 'health' of the forest system in terms of biodiversity. Additionally, because primates form a significant part of the biomass of African forests, and may play an important role in seed dispersal, an assessment of the species richness of the primate fauna may aid assessment of forest conservation priorities.

Recently two surveys have been carried out: a distribution survey of the endemic suntailed guenon Cercopithecus solatus (Harrison, 1988a, Gautier et al., in press) and a nationwide survey of forest elephants (Barnes and Jensen, 1987; Barnes et al., 1991). During this latter survey information on all other mammals encountered was collected (e.g. antelopes [Blom et al., 1990]).

This paper deals with the status and distribution of primates in Gabon, emphasizing species that need special attention and areas that have a high number of primate species.

\section{Gabon}

Gabon is situated on the Equator $\left(2.5^{\circ} \mathrm{N}-4^{\circ} \mathrm{S}\right)$ on the west-central African coast between longitudes $8^{\circ}$ and $15^{\circ} \mathrm{E}$ (Figure 1) and has an area 


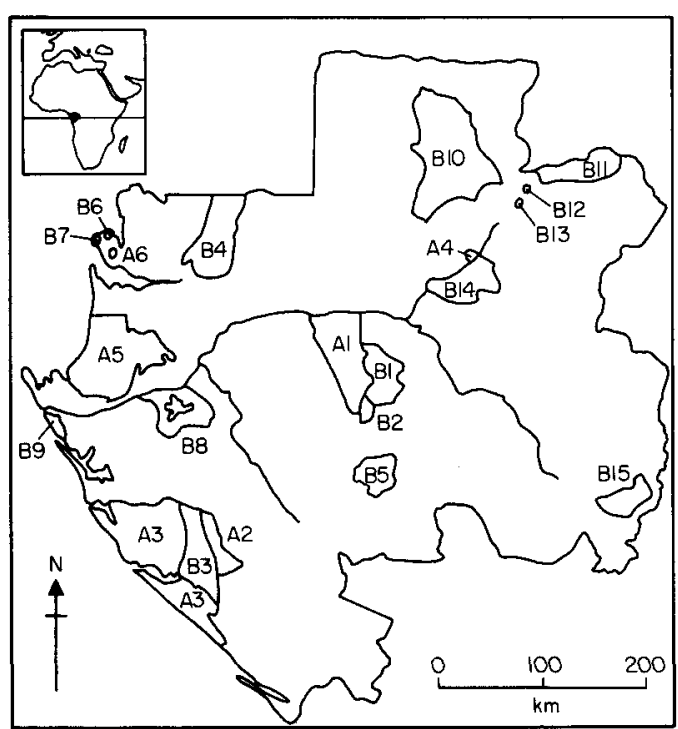

Figure 1. Protected areas in Gabon.

Existing reserves: A1, Lopé; A2, Moukalaba; A3, Sette Cama; A4, Ipassa; A5, Wanga-Wongue; A6, Arboretum de Sibang.

Proposed reserves (Wilks, 1990): B1, Forêt des Abeilles; B2, Mont Iboundji; B3, Mont Doudou; B4, Tschimbele; B5, Milondo; B6, Akanda; B7, Mondah; B8, Lac Onangue; B9, Inguessi; B10, Minkebe; B11, Djoua; B12, Grottes de Belinga; B13, Monts de Belinga; B14, Mingouli; B15, Leconi.

Mont Doudou (B3) plus the existing Moukalaba (A2) and Sette Cama (A3) comprise the proposed Gamba Reserve (see Wilks, 1990).

of $267,667 \mathrm{sq} \mathrm{km}$. Eighty-five per cent of this is covered by Guinea-Congolian tropical rain forest; the rest is a savannah mosaic (Wilks, 1990). Annual rainfall varies from $1400 \mathrm{~mm}$ in the south to more than $3200 \mathrm{~mm}$ along the northern coast (Ministère de l'Education Nationale, 1983).

In 1983 the human population was estimated to be 700,000 (World Bank, 1986), giving a crude density of 2.6 people per sq $\mathrm{km}$. Twofifths of the population live in towns and cities (World Bank, 1986), so the rural population density was only about 1.6 per sq $\mathrm{km}$. Rural exodus to the towns resulted in a net decrease of 10 per cent in the rural population between 1965 and 1983 (Barnes and Jensen, 1987).

Gabonese villagers' main source of protein is bushmeat and freshwater fish. Villages are concentrated along the main roads and rivers, leaving large areas of forest completely uninhabited. Subsistence hunting is heavy around villages but decreases with increasing distance from the village. Commercial hunting, to provide the cities with bushmeat, is usually only practised in areas with easy access to these cities. However, in the case of major cities like Libreville, Port Gentil, and Franceville, the demand is so high that bushmeat comes from distant and remote areas.

Mining, oil exploitation, and logging are important industries, which also have considerable impact on the forest. The completion of the Trans Gabon railway in 1987 has opened up the forests of central Gabon to the timber companies.

\section{Conservation and protection in Gabon}

Of all the primates possibly occurring in Gabon (Table 1) only the apes are included in Class A of the Algiers Convention*. All the other species are included in Class $\mathrm{B}^{+}$. The apes, together with the mandrill and drill, are also listed in Appendix 1 of CITES and therefore international commercial trade in them or their products is forbidden. The other primates are listed in Appendix II, which means that any international trade is regulated and monitored.

The government of Gabon revised its laws on hunting and protection of wild fauna (decret N 189/PR/MEFCR) on 4 March 1987. According to Gabonese law, conventions have priority over national law, so protection follows the international conventions. However, these conventions are usually not enforced, and they are also not adapted to deal with the reality in Gabon. In most rural areas people still depend on subsistence hunting, and primates form an important part of their diet.

Gabon contains six protected areas (Figure

* They may be hunted, killed, captured, or collected only under authorization by the highest competent authority, if required in the national interest or for scientific purposes.

+ They may be hunted, killed or collected only under authorization granted by the competent authority. 
1). There are no national parks, although potential areas for their establishment have been identified and proposed (Figure 1, Nicoll and Langrand, 1986; Wilks, 1990).

Table 1. The primates of Gabon and their conservation status

\begin{tabular}{|c|c|c|c|c|c|}
\hline \multirow[b]{2}{*}{ Species } & \multirow{2}{*}{$\begin{array}{l}\text { Relative } \\
\text { abundance } \\
\text { within } \\
\text { range }\end{array}$} & \multirow[b]{2}{*}{$\begin{array}{l}\text { Conservation } \\
\text { status }\end{array}$} & \multicolumn{2}{|c|}{$\begin{array}{l}\text { Degrees of threat } \\
\text { caused by }\end{array}$} & \multirow[b]{2}{*}{$\begin{array}{l}\text { Present } \\
\text { in }\end{array}$} \\
\hline & & & Hunting & $\begin{array}{l}\text { Habitat } \\
\text { destruction }\end{array}$ & \\
\hline \multicolumn{6}{|l|}{ Family Lorisidae } \\
\hline \multicolumn{6}{|l|}{ Subfamily Lorisinae } \\
\hline Arctocebus calabarensis & $?$ & $\mathrm{~K}$ ? & 1 & 1 & $\mathrm{~A} 1, \mathrm{~A} 4$ \\
\hline Perodicticus potto & $?$ & NT? & 1 & 2 & $\mathrm{~A} 1, \mathrm{~A} 4$ \\
\hline \multicolumn{6}{|l|}{ Subfamily Galaginae } \\
\hline Galago alleni & $?$ & $\mathrm{~K}$ ? & 1 & 3 & $\mathrm{~A} 4$ \\
\hline Galago demidovii & $?$ & NT? & 1 & 1 & $\mathrm{~A} 1, \mathrm{~A} 2, \mathrm{~A} 4$ \\
\hline Galago elegantulus & $?$ & NT? & 1 & 2 & $\mathrm{~A} 2, \mathrm{~A} 4$ \\
\hline \multicolumn{6}{|l|}{ Family Cercopithecidae } \\
\hline \multicolumn{6}{|l|}{ Subfamily Cercopithecinae } \\
\hline Cercocebus torquatus & $\operatorname{xxxx}$ & $\mathbf{R}$ & 2 & 1 & $\mathrm{~A} 2, \mathrm{~A} 3$ \\
\hline Cercocebus galeritus & $x x x ?$ & $\mathrm{~V}$ & 3 & 1 & None \\
\hline Cercocebus albigena & $x x x$ & NT & 2 & 1 & $\mathrm{~A} 1, \mathrm{~A} 4$ \\
\hline Mandrillus sphinx & $x$ & $\mathrm{~V}$ & 3 & 2 & $\mathrm{~A} 1, \mathrm{~A} 4$ \\
\hline Mandrillus leucophaeus & $?$ & $\mathrm{E}$ & 3 & 2 & (A1) \\
\hline Cercopithecus neglectus & $x x x$ & $\mathbf{R}$ & 2 & 1 & A4 \\
\hline Cercopithecus solatus & $x x x ?$ & $\mathrm{R}$ & 3 & 2 & None \\
\hline Cercopithecus nictitans & $\operatorname{xxxx}$ & NT & 3 & 1 & All \\
\hline Cercopithecus cephus & $x x x x$ & NT & 2 & 1 & All \\
\hline Cercopithecus pogonias & $x x x$ & NT & 2 & 1 & $\mathrm{~A} 1, \mathrm{~A} 4$ \\
\hline Cercopithecus aethiops & $?$ & $\mathrm{E}$ & 3 & 1 & None \\
\hline Miopithecus talapoin & $?$ & NT? & 1 & 1 & A4 \\
\hline \multicolumn{6}{|l|}{ Subfamily Colobinae } \\
\hline Colobus satanas & $x x$ & 1 & 2 & 3 & A1 \\
\hline Colobus quereza & $x x x$ & $\mathrm{R}$ & 2 & 1 & None \\
\hline \multicolumn{6}{|l|}{ Family Pongidae } \\
\hline Pan troglodytes & $x x x$ & NT & 2 & 2 & All \\
\hline Gorilla gorilla & $x x x$ & $\mathrm{NT}$ & 2 & 1 & All \\
\hline
\end{tabular}

Key

Relative abundance within range:?, unknown or classification tentative because of lack of information; $x x x x$, abundant; $x x x$, common; $x x$, sporadic; $x$, rare.

Conservation status. The primate species of Gabon were assigned IUCN categories (Lee et al., 1988):

$E$, Endangered, taxa in danger of extinction and whose survival is unlikely if the causal factors continue to operate. V, Vulnerable, taxa believed likely to move into the Endangered category in the near future should the causal factors continue to operate. R, Rare, taxa with small populations that are at present not Endangered or Vulnerable, but are at risk. I, Indeterminate, taxa known to be Endangered, Vulnerable or Rare, but where there is not enough information to say which of the three categories is appropriate. $K$, Insufficiently Known, taxa that are suspected, but not definitely known to belong to any of the above categories, because of lack of information. NT, Not Threatened, taxa that are not considered to be threatened at the present time.

Degree of threat from hunting or habitat destruction: 1 , small; 2, moderate; 3 , severe.

Present in (see Figure 1): A1, Lopé; A2, Moukalaba; A3, Sette Cama; A4, Ipassa; A5, Wanga-Wongue. 


\section{Methods}

The species is the taxonomic unit used (see Table 1). Classification follows that adopted by the Primate Specialist Group of the IUCN/ Species Survival Commission (e.g. Oates, 1985; Lee et al., 1988). Twenty-one species are recognized as 'possibly' occurring in Gabon.

The results presented in this paper were compiled by the first author from data obtained during the Forest Elephant Survey (early 1985 to October 1988) and the Sun-tailed Guenon Survey (1986 and 1987). Most data are from fieldwork for the Forest Elephant Survey. Transects were carried out using standard line-transect methods (Burnham et al., 1980; Barnes and Jensen, 1987; Koster and Hart, 1988) and varied in length from 1 to 20 $\mathrm{km}$. Transect locations were chosen more-orless randomly along roads and rivers. Some transects started directly perpendicular to the road or river, others started $10 \mathrm{~km}$ inside the forest. A total of 45 transects $(565 \mathrm{~km})$ were carried out. Information from the literature (e.g. Nicoll and Langrand, 1986; checklists Ipassa and Lopé) and local people (mostly hunters) was also included. Data from the Sun-tailed Guenon Survey were collected by detailed interviews with local hunters (Gautier et al., in press). All data were interpreted using the criteria in Table 2.

In order to visualize the results a grid-system was adopted (see Figure 2). Each grid square corresponds to a square with halfdegree sides and is approximately $55 \times 55 \mathrm{~km}$ (about $3000 \mathrm{sq} \mathrm{km}$ ).

There was no information available for 41 squares, or about $75,600 \mathrm{sq} \mathrm{km}$ (28 per cent) of the country. Complete coverage (i.e. at least one transect of at least $5 \mathrm{~km}$ carried out, during which several days were spent in the field) was achieved in 31 squares, with partial coverage (less-complete field observations and no transects, or transects less than $5 \mathrm{~km}$ long) of an additional 41 squares (see Figure 2). Very few data were gathered on the nocturnal primates (bushbabies and pottos) and some cryptic species (such as talapoin monkeys).

Table 2. Interpretation criteria for different types of data

\begin{tabular}{|c|c|c|c|}
\hline & Definitely present & Probably present & Possibly present \\
\hline Sighting & All species & & \\
\hline Hearing* & $\begin{array}{l}\text { M. sphinx } \\
\text { C. nictitans } \\
\text { G. gorilla } \\
\text { P. troglodytes }\end{array}$ & $\begin{array}{l}\text { C. albigena } \\
\text { C. torquatus } \\
\text { C. cephus }\end{array}$ & \\
\hline Nest & & $\begin{array}{l}\text { G. gorilla } \\
\text { P. troglodytes }\end{array}$ & \\
\hline
\end{tabular}

Found dead/killed All species

For sale $^{+} \quad$ All species

Recent literature All species

$\begin{array}{ll}\text { Local people } & \text { All species }\end{array}$

* Those species with very distinct vocal characteristics (e.g. loud calls) were marked as definitely present if
heard. Those with less distinctive vocalization were recorded as probably present if heard.
${ }^{+}$Although we were sure about the species concerned, we marked the animals for sale as probably present,
because they could have been killed elsewhere (in most cases the game for sale is hunted close to the village;
large cities were excluded). 


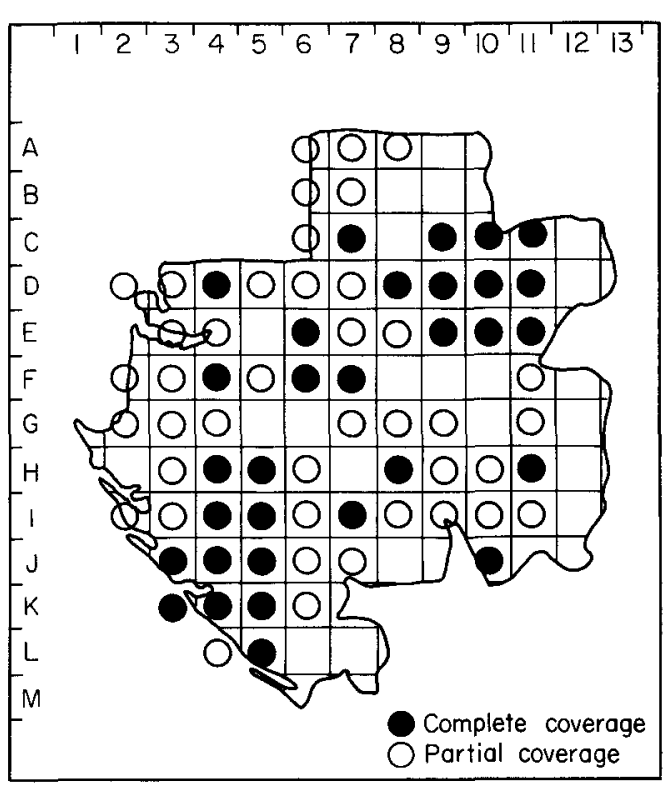

Figure 2. Blocks of Gabon covered by this survey during the period 1985-88. Each block corresponds to a square with half-degree sides of approximately $55 \mathrm{~km}$ (about $3000 \mathrm{sq} \mathrm{km}$ ).

\section{Species accounts}

Table 1 summarizes the primates possibly occurring in Gabon and their relative abundance within their range. Their conservation status, the degree of threat posed by hunting or habitat destruction, and the protected areas in which the species is thought to occur are also presented.

\section{Bushbabies and pottos}

Distribution and population. All the five species of Lorisidae have been recorded at the Ipassa Reserve. The most common one is Galago demidovii at average densities of 50 per sq $\mathrm{km}$, followed by G. alleni and G. elegantulus, both at average densities of 15 per sq km (CharlesDominique, 1974). Perodicticus potto and Arctocebus calabarensis appear to be less common, with average densities of eight and two per sq $\mathrm{km}$, respectively (Charles-Dominique, 1974). Both Perodicticus and Arctocebus were recorded from central Gabon (Lopé) and the north-east (around Ipassa) and the former was also found round Oyem (Figure 3). Galago alleni appears to have a more limited distribution and was only found in the north-east. The few data available for the other two galagos suggest that they are more widespread, from the north-east to south-west.

Threats. All members of the Lorisidae are occasionally hunted, but the only major threats are habitat destruction through forestry and clearance for cultivation. Those species that are able to inhabit secondary forest (Arctocebus and $G$. demidovii) may survive in areas that are only selectively logged, whereas G. alleni, which seems restricted to primary forest, may be more at risk (Charles-Dominique, 1974).

\section{Mandrills and mangabeys}

Distribution and population. The distribution of the mandrill Mandrillus sphinx is more restricted than previously reported (Malbrant and MacLatchey, 1949; Grubb, 1973; Harrison, 1988b). The Ivindo and Ogooué Rivers form the western limits of its distribution (Figure 3 ) (Harrison, 1988b; this study). The mandrill is absent from the coastal region west of the River Ngounie between the Rivers Ogooué and Nyanga, although it does occur south of the Nyanga. Some 'leaking' may occur across these boundaries.

It is still unclear whether or not the drill $M$. leucophaeus occurs in Gabon, and thus whether the mandrill and drill are sympatric (as implied by Malbrant and MacLatchey, 1949; Nicoll and Langrand, 1986; Tutin and Fernandez, 1987) or allopatric (Grubb, 1973; Harrison, 1988b). Earlier reports and museum specimens were critically examined by Grubb (1973), who concluded that most of the evidence for sympatry was erroneous. However, recently both Nicoll and Langrand (1986) and E. A. Williamson (pers. comm.) claim to have seen drills in the Lopé Reserve (Figure 3). These observations need to be confirmed with an animal in the hand or a good photograph, because it is very easy to confuse the two in the dim forest, especially because very dark mandrills have been seen in the same area at Lopé (Alers and Blom, pers. obs.). 

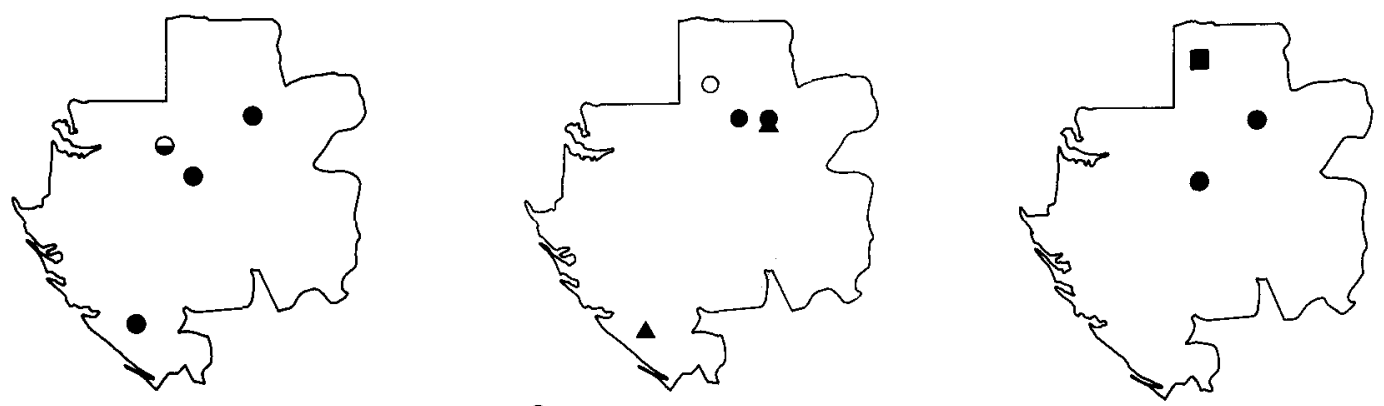

O Galago alleni

$\triangle$ Galogo elegantulus
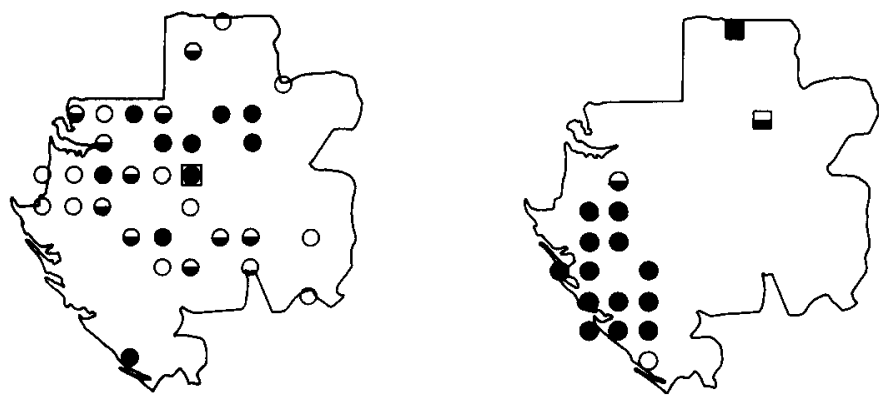

$\square$ Cercocebus galerifus

O Mondrillus sphinx

$\square$ Mondrillus leucophoeus

O cercocebus torquatus

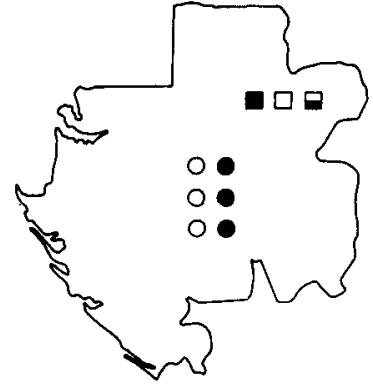

O Cercopithecus solatus

$\square$ Cercopithecus neglectus

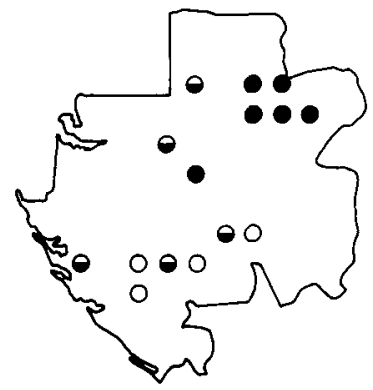

Cercopithecus pogonios

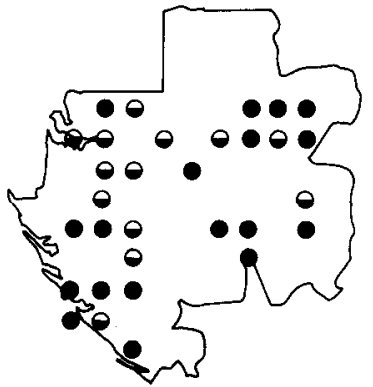

Cercopithecus cephus

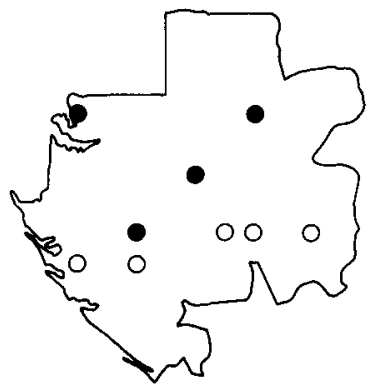

Miopithecus folopoin
Perodicticus potto

- Perodicticus potio +

Arctocebus colaborensis

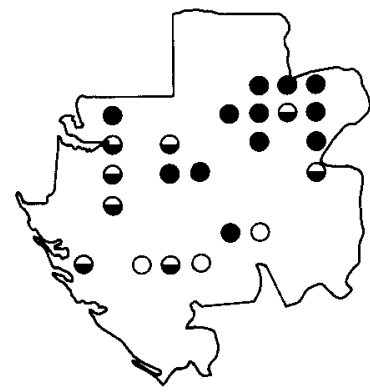

Cercocebus albigeno

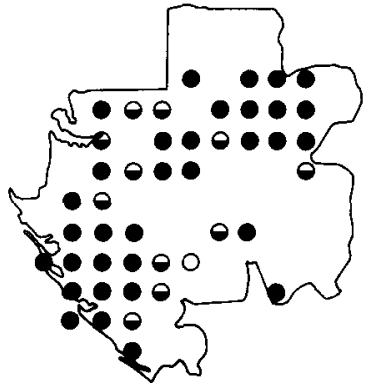

Cercopithecus nictitans

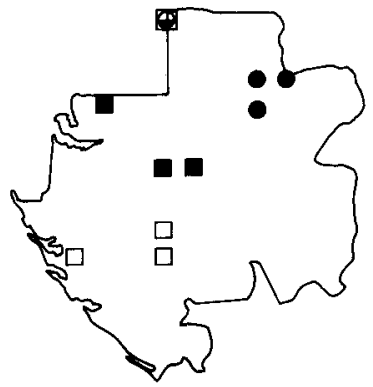

O Colobus guereza

$\square$ Colobus satanus

Definitely present $\odot$ Probably present O Possibly present

Figure 3. Records of current primate distribution in Gabon obtained during this survey (see Table 2 for criteria used). 


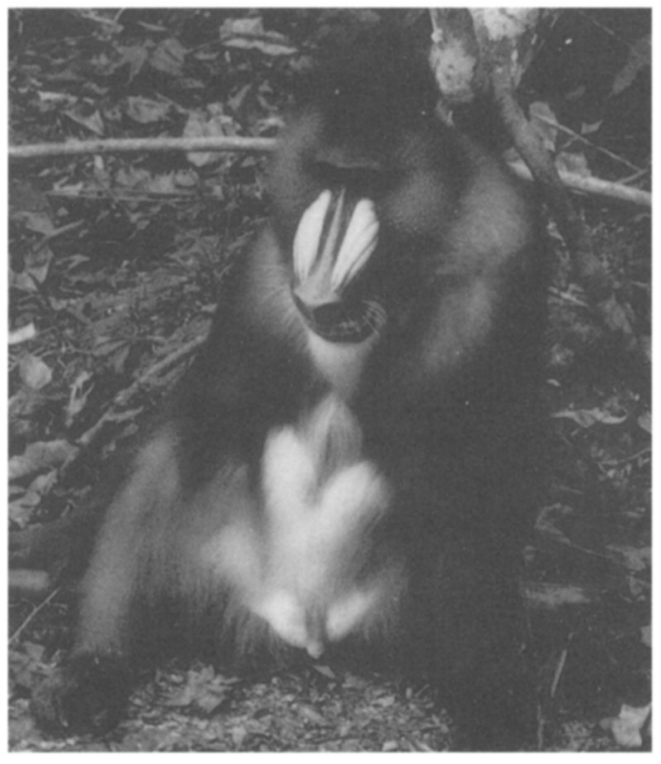

The red-capped mangabey Cercocebus torquatus occurs only in the coastal area, where the mandrill is absent or only at low density. It does not seem to cross the Ngounie River (Figure 3). We do not know whether it occurs north of the Estuaire de Gabon towards Cocobeach, but it is probable that it does, because it occurs further north along the coast and along the major rivers of Mbini, Equatorial Guinea (J. Juste, pers. comm.). It may be absent south of the River Nyanga.

The grey-cheeked mangabey C. albigena is probably present throughout the forest zone in Gabon, but the crested mangabey $C$. galeritus is limited to the extreme north-east (Figure 3).

Status. It is difficult to assess the status of such a wide-ranging primate as the mandrill. It appears to be relatively common in the north and it is also common in the adjacent part of Mbini, Equatorial Guinea (J. Juste, pers. comm.; Alers and Blom, pers. obs.). However, in general mandrills are rare and live at low density (Harrison, 1988b; this study) and there is some evidence to suggest their numbers are declining (Harrison, 1988b). Mangabeys appear common within their ranges.

Threats. Both mandrills and mangabeys are hunted for food. Mandrills in particular are

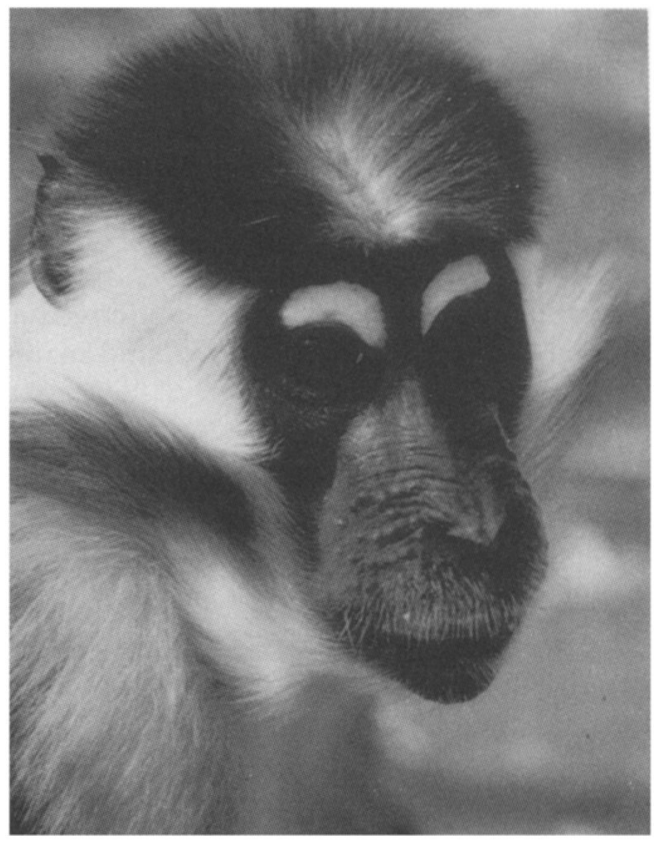

Above left: Mandrill Mandrillus sphinx (A.T. C. Feistner).

Above right: Red capped mangabey Cercocebus torquatus (J. P. Gautier).

Below: Grey-cheeked mangabey Cercocebus albigena (J. P. Gautier).

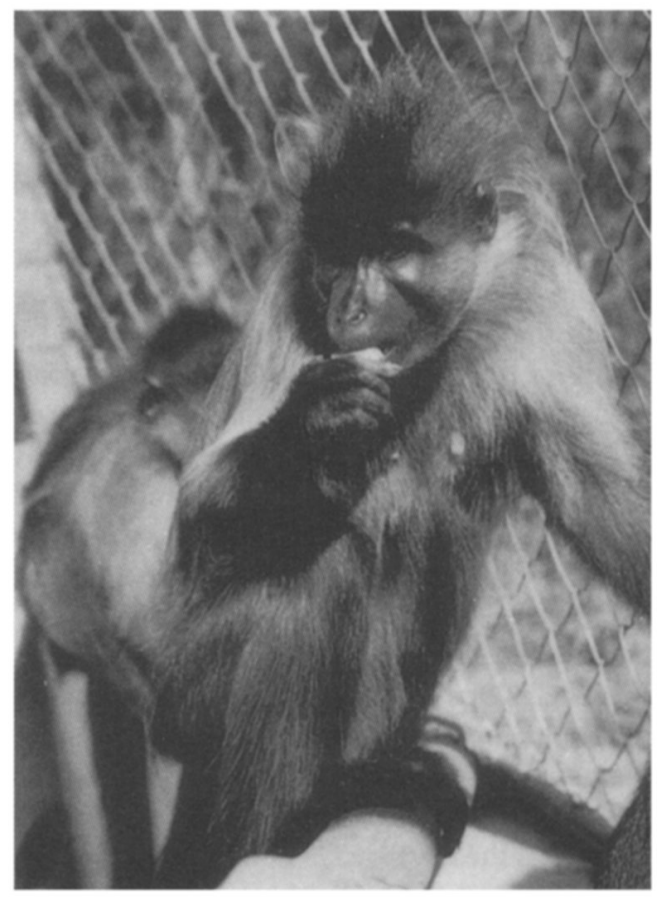


highly prized food items (Sabater $\mathrm{Pi}$ and Groves, 1972; this study). Groups of mandrills advertise their presence through their loud vocalizations and can then be chased up into trees by hunters' dogs, where they form easy targets for hunters with guns. In this way several animals may be killed in one encounter. Mandrills and some of the semi-terrestrial mangabeys are also captured in ground snares and occasionally kept as pets.

The grey-cheeked mangabey, which is highly arboreal, seems particularly affected by habitat destruction and its relative abundance is significantly reduced in degraded areas (Gautier et al., in press).

\section{Guenons}

Distribution and population: The De Brazza monkey Cercopithecus neglectus is restricted to the extreme north-east of Gabon (Figure 3) and does not occur south of Makokou. It does not penetrate very far westwards, although the exact limit is unclear. It is usually found only alongside rivers.

The recently discovered sun-tailed guenon Cercopithecus solatus is endemic to central Gabon (Harrison, 1988a). It occurs in a small area just east of the Lopé Reserve, bounded on the north and east by the Ogooué, Lolo, and Bouenguidi rivers and in the west by a change in forest type near the Offoue River. Its range is thus restricted on three sides by natural barriers. The southern limit is less clear, but appears connected to an increase in altitude, which the species avoids. It is present to the south of the Koulamoutou-Mimongo road, but not much further south (Gautier et al., 1987; Gautier et al., in press).

The other three guenons - the moustached guenon $C$. cephus, the greater spot-nosed guenon $C$. nictitans, and the crowned guenon C. pogonias - are probably all present throughout the forest zone of Gabon (Figure 3). Two distinct allopatric subspecies of the moustached guenon are found: C.c. cephodes, which seems to be limited to the south-west (south and west of the Ogooue); and C. c. cephus in the rest of the country.

Malbrant and MacLatchey (1949) reported

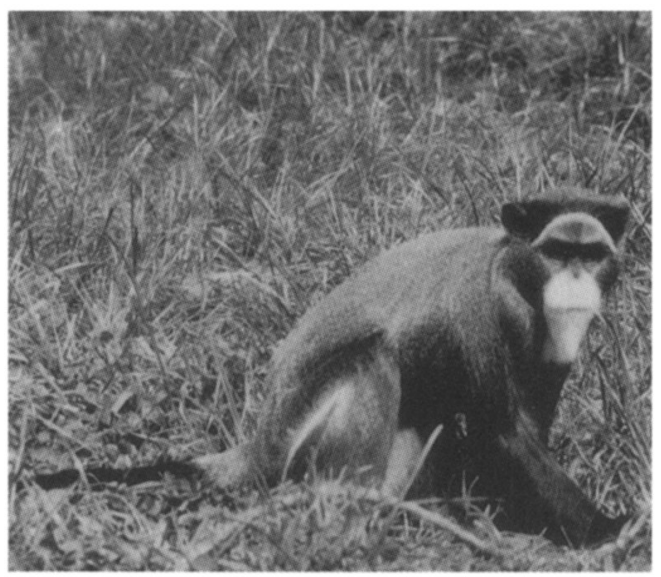

De Brazza monkey Cercopithecus neglectus (J. P. Gautier).

the vervet $C$. aethiops from the south-west of Gabon. We were unable to discover any evidence of its presence, although we were unable to visit the extreme south-west (south of Mayumba) where it may still survive.

Although we have few records of talapoin monkeys Miopithecus talapoin, the species is so widespread (Figure 3) that we can assume that it is probably present throughout the forest zone of Gabon. It is particularly associated with riverine habitats.

Status. It appears that almost all the guenons are either common or abundant within their ranges.

Threats. All guenons, with the exception of the talapoin, are hunted for their meat. The de Brazza monkey is relatively easy to kill once detected because of its slow movements and habit of 'freezing' rather than fleeing (GautierHion and Gautier, 1978). The males of greater spot-nosed guenons are also easily shot by hunters, who lure them in by imitating their characteristic loud calls. This may have a severe effect on population structure by changing sex ratios.

The talapoin monkey is widely reported to steal cassava from streams, placed there for soaking before preparation. Because of its small size the talapoin is not usually hunted for meat, but may be trapped as a reprisal for crop-raiding. 


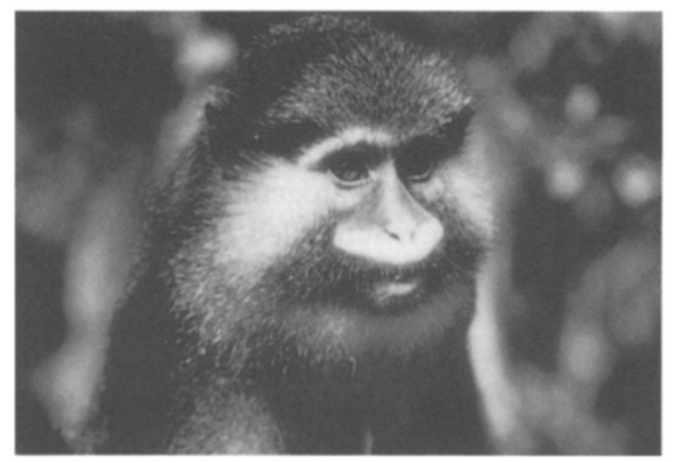

Above: Moustached guenon Cercopithecus cephus (J. P. Gautier).

Right: Crowned guenon Cercopithecus pogonias (J. P. Gautier).

The spot-nosed and crowned guenons, which are highly arboreal, appear to be particularly affected by habitat destruction and their relative abundance is significantly reduced in degraded areas (Gautier et al., in press).

\section{Colobus monkeys}

Distribution and population. The black colobus Colobus satanas is present in the Monts de Cristal, the Lopé Reserve, and the adjacent Forêt des Abeilles (Figure 3). It is possibly also present south of Lopé, to the west of Mandji, and around Bitam. Furthermore, there are unconfirmed reports of sparse populations east of the Ogooué and Ivindo Rivers (Harrison, in Lee et al., 1986). This species has a limited and scattered distribution. Density was estimated at 26 animals per sq $\mathrm{km}$ in the Lopé Reserve and at $25-30$ per sq $\mathrm{km}$ in the Forêt des Abeilles. However, densities vary from area to area (Harrison and Hladik, 1988).

The guereza $C$. guereza is restricted to the north-east of Gabon, north of Makokou.

Status. Even within its limited range the black colobus is only locally common. Its status is still indeterminate, but numbers are probably declining. The guereza is common.

Threats. The black colobus appears to be particularly vulnerable to all forms of forest felling because it needs high-canopy forest and may be unable to survive in secondary

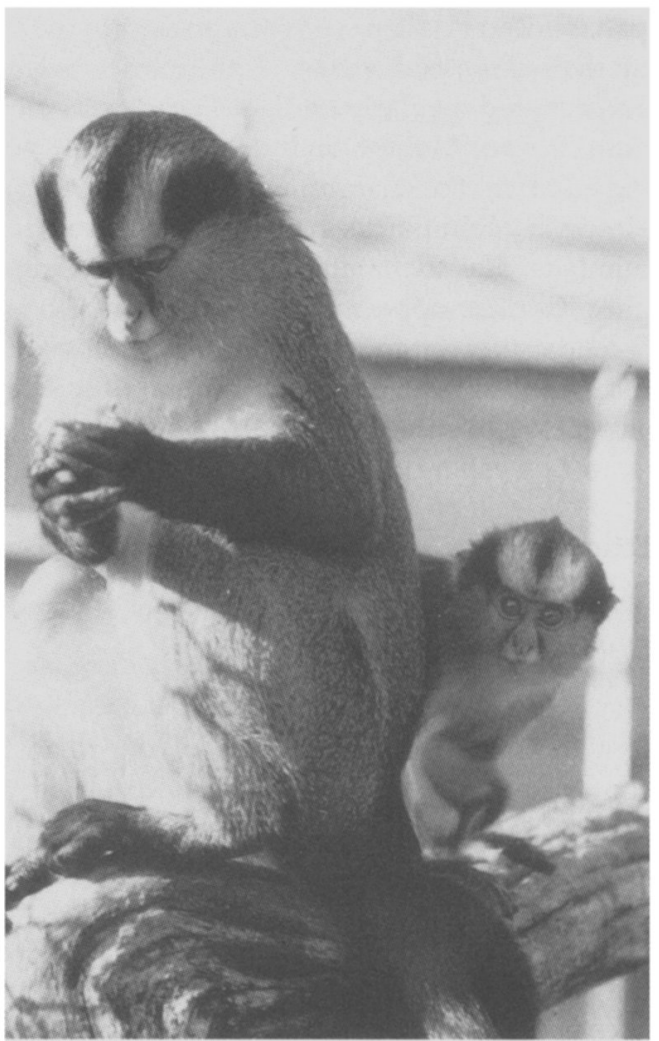

forest (Oates, 1985; Gartlan, in Lee et al., 1988; Gautier et al., in press). This means that even selective logging, which is occurring over most of its range (even within the Lopé Reserve), may pose a serious threat. It is not hunted by some tribes due to taboos on eating its meat, which is also reported to taste bad.

Apes

The apes, chimpanzees Pan troglodytes troglodytes and gorillas Gorilla gorilla gorilla, were censused in the early 1980s (Tutin and Fernandez, 1984). Gabon is an important sanctuary for both species, with population estimates of approximately 64,000 and 35,000 , respectively. Chimpanzees were found in all types of forest, being absent only from areas of intense human activity. The distribution of gorillas was similar, except that they were absent from the forest blocks in the south-eastern savannah areas (Tutin and Fernandez, 1984). We were able to confirm that chim- 
panzees and gorillas were still present in most of their described range. Both species were encountered regularly and gorillas were abundant in the Mont Doudou, which may be included in the Gamba Reserve (Figure 1). However, chimpanzees may be declining in numbers due to habitat destruction by logging. Gorillas appear better able to adapt to secondary forest and therefore appear less at risk. Apes are still sometimes offered for sale as pets.

\section{Discussion}

\section{Distribution and population}

There are at least 19 species of primates present in Gabon, making it one of the richest countries in the world for this group. Many species are still widespread in Gabon, although some, such as the de Brazza monkey and crested mangabey just range across the border into Gabonese territory. One species, the sun-tailed guenon, is endemic. The presence of drill and vervet needs to be confirmed.

The mandrill and red-capped mangabey appear to be more-or-less allopatric. The mandrill is the more widely distributed, but its range barely overlaps that of the mangabey, which occupies most of the coastal zone. However, these species are sympatric in parts of Cameroon, e.g. at Campo (Hoshino, 1985; Mitani, 1989). The other semi-terrestrial monkeys (e.g. sun-tailed guenon, de Brazza monkey) overlap to some extent with mandrills, but densities of mandrills seem to be low in these areas.

There are no overall population estimates, except for the apes, although some information exists about densities of several species, such as bushbabies and black colobus, in some areas. The data should be treated with caution because many are several years old and population numbers may have changed.

\section{Status}

The status of all primates in Gabon is given in Table 1. Although perhaps 10 species are not threatened, insufficient data are available to assess the status of some of the nocturnal prosimians and status surveys of the threatened mandrill and black colobus are urgently needed. These species, together with the redcapped mangabey, sun-tailed guenon, gorilla, and chimpanzee are considered to be under severe threat on a continental scale (Lee $e t$ al., 1988).

\section{Threats}

Hunting and habitat destruction are the main threats to the primates of Gabon. The major problem at the moment is the opening up of previously inaccessible areas by logging companies and the Trans Gabon railway. This usually results in a subsequent rapid increase in human population and then mounting hunting pressure. This problem is likely to be exacerbated by the proposed extension of the railway towards Belinga (north-east Gabon) and the exploitation of huge iron-ore deposits in this area.

Twelve-bore shotguns are used for hunting primates. The semi-terrestrial monkeys and even apes are also caught in snares, which have usually been set to catch duikers, cane rats, and porcupines.

Hunting for subsistence (traditional hunting) seldom causes threats to the survival of primate species; it is organized commercial hunting that severely compromises primate populations. The increasing demand for bushmeat from urban centres such as Libreville and Port Gentil is causing major problems in some areas (e.g. Monts de Cristal east of Libreville).

Huge areas are being logged, albeit selectively, which may result in loss of habitat for some specialized species. Nicoll and Langrand (1986) estimated that the percentage of virgin forest in Gabon would fall from 38 per cent to 24 per cent between 1986 and 1997 as a result of expanding logging activities. Selective logging usually means that, on average, one tree per ha is felled in the interior, but this cut rate is higher in more accessible areas, such as the coast (Wilks, 1990). Gaps in the canopy caused by falling trees, the construction of logging 
roads, and resultant soil compaction all influence forest structure. Additionally, the logging roads provide access for hunters.

\section{Conservation measures}

Gabon is one of the very few tropical countries in which the rural population is diminishing. Deforestation trends indicate that Gabon and Congo will be the only countries in tropical Africa that will not lose a large proportion of their forests during the next 50 years (Barnes, 1990). This, combined with the extraordinary biodiversity and relatively high per capita income, places Gabon in a unique position. Together with perhaps Congo, it is the country with the greatest potential for long-term conservation of intact rain-forest ecosystems in Africa (McShane, 1990).

However, to ensure the conservation of Gabonese rain forest and the primates and other fauna and flora it contains, various measures are needed. In order to provide the information needed and to help ensure the continuing existence of Gabon's primate diversity we recommend the following:

* further surveys into the distribution and status of threatened species (mandrill, black colobus) and further research into the ecology and behaviour of these species and the suntailed guenon;

* a ban on large-scale commercial hunting. In practice this could be relatively easily achieved by preventing the transport of bush meat. Research into the feasibility of producing game commercially, e.g. farming cane rats and porcupines, should be encouraged;

* law enforcement inside reserves, thus ending the illegal logging and hunting currently occurring;

* establishment of a programme for environmental education and public awareness, especially around protected areas.

The existing reserves (Figure 1) are currently insufficient, both in terms of size and degree of protection, to protect the enormous diversity of wildlife in Gabon. The data presented in this paper, together with new information on antelopes (Blom et al., 1990), elephants (Barnes et al., 1991), birds (P.
Christy, pers. comm.) and trees (C. Wilks, pers. comm.) have resulted in proposals for the establishment of several new reserves and national parks (Wilks, 1990; Figure 1) and bases for management plans for each protected area in Gabon (e.g. Nicoll and Langrand, 1986; Wilks, 1990).

Gabon will need outside financial and technical assistance for these and other conservation measures. If these are forthcoming then Gabon has an excellent chance of preserving its enormous diversity of primates and other wildlife.

\section{Acknowledgments}

The fieldwork for the elephant survey was financed by Wildlife Conservation International (New York Zoological Society) and the Royal Society. We thank the Gabonese Government for permission to work in Gabon. Thanks for additional support to $M$. P. Posso, Directeur de I'Institut de Recherche en Ecologie Tropicale and the personnel of Direction de la Faune et de la Chasse, CENAREST, and CIRMF Thanks to P. H. Chanjou, P. Christy, R. W. Cooper, S. Evans, M. Fernandez, J-P. Gautier, A. M. Louis, H. Morand, J. P. Pasquier, C. E. G. Tutin, and C. Wilks for additional data and support. The US Peace Corps and US Embassy, the logging companies in Gabon, SHELL, EUROTRAG, and our Gabonese friends all have our thanks. Earlier drafts benefited from comments by P. Lee and C. E. G. Tutin.

\section{References}

Barnes, R.F.W. 1990. Deforestation trends in tropical Africa. Afr. J. Ecol. 28, 161-173.

Barnes, R.F.W. and Jensen, K.L. 1987. How to count elephants in forest. IUCN African Elephant and Rhino Specialist Group, Technical Bulletin, 1, 1-6.

Barnes, R.F.W., Barnes, K.L., Alers, M.P.T. and Blom, A. 1991. Man determines the distribution of elephants in the rainforests of northeastern Gabon. Afr. J. Ecol. 29, 54-63.

Blom, A., Alers, M.P.T. and Barnes, R.F.W. 1990. Gabon. In Antelopes. Global Survey and Regional Action Plans. Part 3. West and Central Africa. (compilers R. East and the IUCN/SSC Antelope Specialist Group). IUCN, Gland Switzerland and Cambridge, UK.

Burnham, K.P., Anderson, D.R. and Laake, J.L. 1980. Estimation of density from line transect sampling of biological populations. Wildl. Monogr. No. 72, $201 \mathrm{pp}$

Charles-Dominique, P. 1974. Ecology and feeding 
behaviour of five sympatric lorisids in Gabon. In Prosimian Biology (eds R. D. Martin, G. L. Doyle, and A. C. Walker), pp. 131-150, Duckworth, London.

Gautier, J.P. and Gautier-Hion, A. 1969. Les associations polyspecifiques chez les Cercopithecidae du Gabon. Terre et Vie, 116, 164-201.

Gautier, J.P., Moysan, F., Loireau, J.N. and Feistner, A.T.C. 1987. Une nouvelle espèce Gabonaise de cercopithèque. Unpubl. report for Eaux et Forets.

Gautier, J.P., Moysan, F., Feistner, A.T.C., Loireau, J.N. and Cooper, R.W. In press. Geographical distribution of Cercopithecus (lhoesti) solatus a guenon endemic to Gabon. Terre et Vie.

Gautier-Hion, A. and Gautier, J.P. 1978. Le singe de Brazza: une stratégie originale. Zeitschr. Tierpsychol. 46, 84-104.

Grubb, P. 1973. Distribution, divergence and speciation of the drill and mandrill. Folia Primatol. 20, 161-177.

Harrison, M.J.S. 1988a. A new species of guenon (genus Cercopithecus) from Gabon. J. Zool. Lond. 215, 561-575.

Harrison, M.J.S. 1988b. The mandrill in Gabon's rainforests: ecology, distribution and status. Oryx, 22, 218-228.

Harrison, M.J.S. and Hladik, C.M. 1986. Un primate granivore: le colobe noir dans le forêt du Gabon; potentialite du comportement alimentaire. Terre et Vie, 41, 281-298.

Hoshino, J. 1985. Feeding ecology of mandrills (Mandrillus sphinx) in Campo Animal Reserve, Cameroon. Primates, 25, 295-307.

Koster, S.H. and Hart, J.A. 1988. Methods of estimating ungulate populations in tropical forests. Afr. J. Ecol. 26, 117-126.

Lee, P.C., Thornback, J. and Bennett, E.L. 1988. Threatened Primates of Africa The IUCN Red Data Book. IUCN Gland, Switzerland and Cambridge, UK.

Malbrant, R. and MacLatchey, A. 1949. Faune de l'Equateur Africain Francais. 2. Mammifères. Lechevalier, Paris.

McShane, T.O. 1990. Conservation before the crisis an opportunity in Gabon. Oryx, 24, 9-14.
Ministère de l'Education Nationale. 1983. Atlas $d u$ Gabon. EDICEF, Paris.

Mitani, M. 1989. Cercocebus torquatus: Adaptive feeding and ranging behaviors related to seasonal fluctuations of food resources in the tropical rain forest of south-western Cameroon. Primates, 30, 307-323.

Nicoll, M. and Langrand, O. 1986. Conservation et utilisation rationelle des ecosystèmes forestieres du Gabon. WWF/IUCN Project 3247.

Oates, J.F. 1985. Action Plan for African Primate Conservation 1986-90. IUCN/SSC Primate Specialist Group. IUCN, Gland.

Pages, E. 1972. Comportement agressif et sexuel chez les pangolins arboricoles (Manis tricuspis et M. longicauda). Biol. Gabonica, 1, 3-62.

Sabater Pi, J. and Groves, C. 1972. The importance of higher primates in the diet of the Fang of Rio Muni. Man, 7, 239-243.

Tutin, C.E.G. and Fernandez, M. 1984. Nation-wide census of gorilla (Gorilla g. gorilla) and chimpanzee (Pan t. troglodytes) populations in Gabon. Am. J. Primatol. 6, 313-336.

Tutin, C.E.G. and Fernandez, M. 1987 Gabon: A fragile sanctuary. Prim. Conserv. 8, 160-161.

Wilks, C. 1990. La Conservation des Ecosystèmes Forestieres $d u$ Gabon. IUCN, Gland, Switzerland and Cambridge, UK, 215pp.

World Bank 1986. Population Growth and Policies in Sub-saharan Africa. The World Bank, Washington.

A. Blom, M. P. T. Alers, R. F. W. Barnes, K. L. Barnes, Wildlife Conservation International, New York Zoological Society, Bronx, New York 10460, USA.

A. T. C. Feistner, Centre International de Recherches Médicales de Franceville, BP 769, Franceville, Gabon (Current address: Jersey Wildlife Preservation Trust, Les Augrès Manor, Trinity, Jersey JE3 5BF, Channel Islands.)

Correspondence and reprint requests to A. T. C. Feistner. 